\title{
Interaction between Financial Development and Sustainable Development, Evidence from Developing Countries: A Panel Data Study
}

\author{
Badri Houda ${ }^{1} \&$ Mazigh Jaidane Lamia ${ }^{2}$ \\ ${ }^{1}$ Doctoral researcher, Department of Economics, Faculty of Economic Sciences \& Management, University of \\ Sousse, Tunisia \\ ${ }^{2}$ Master of Conferences in Economics, Faculty of Economics Sciences \& Management of Mahdia, Tunisia \\ Correspondence: Badri Houda, Doctoral researcher, Department of Economics, Faculty of Economic Sciences \& \\ Management, University of Sousse, Tunisia. E-mail: badri_houuda@yahoo.fr
}

Received: December 10, 2015

Accepted: December 30, 2015

Online Published: January 25, 2016

doi:10.5539/ijef.v8n2p243

URL: http://dx.doi.org/10.5539/ijef.v8n2p243

\begin{abstract}
Sustainable development is a complex concept of the world's and is an major challenge for all countries. For that reason, some authors have argued the essential role of financial development to stimulate the various pillars of this concept, respectively, the economic pillar, ecological and social. The objective of this paper is to study how the financial system in developing countries contributes to the improvement of sustainable development, focusing particularly on the environmental pillar. Estimations are conducted with a panel data of 20 development countries over the period of 1995-2011 using Econometrics static panel. Our findings show that financial system in developing countries, generally has a favorable impression on Environmental, unfavorable effect for industrial investment and economic growth, but in contrast, in insignificant effect for domestic credit provided by banking sector relative to GDP and Life expectancy at birth, total (years).
\end{abstract}

Keywords: financial development, environmental sustainability, static panel

\section{Introduction}

Sustainable development is a complex concept that covers cross-cutting issues. It affects environmental issues, social, and economic it is possible to identify. This concept was appeared in 1987 by the report of the World Commission on Environment and Development, said Commission "Brundtland". It was taken over by the UN General Asemblée in 1992 (International Training Centre of the International Labour Organization, 2014).

Therefore, two concepts have emerged, the concept of needs that are paramount the poor and the notion of limits imposed by the state of technology and the social state to the environment's ability to meet the needs of both present and future.

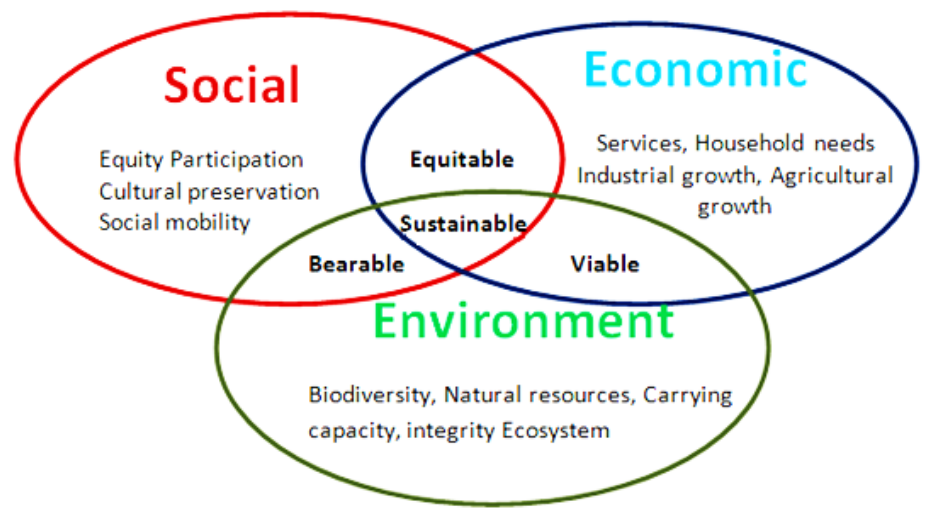

Figure 1. Pillars of sustainable development 
The World Commission on Environment and Development in 1987 (WCED has published a report on sustainable development. It was popularized in Our Common Future. This, also known as the Brundtland Report (United Nations Headquarters, 2010), contains the "classical" definition of sustainable development: "development which meets the needs of the present without compromising the ability of future generations to meet their own need". The fact that the General Assembly of States-Nations has accepted the report gives the term political salience.

And in 1992 the principles of sustainable development were setted by leaders at the United Nations conference on Environment and Development (UNCED) in Rio de Janeiro, Brazil.

Various definitions of Sustainable development have emerged over the past two decades since it is a fluid concept. A few common principles tend to be emphasized in spite of an on-going debate on the actual meaning. The first is a commitment to equity and fairness, in that priority should be given to the improving the conditions of the world's poorest and decisions should consider the rights of future generations. The second is a long-term view that underlines the precautionary principle, i.e., "where there are threats of serious or irreversible damage, lack of full scientific certainty shall not be used as a reason for postponing cost-effective measures to prevent environmental degradation" (Rio Declaration on Environment and Development, Principle 15). Third, sustainable development incarnates integration, and understanding and acting on the complex interconnections that is between the environment, economy, and society. This is not a balancing act or a playing of one issue off against the other, but admitting the interdependent nature of these triple pillars.

In spite of a general acceptance that sustainable development appeals a convergence between the three pillars of economic development, environmental protection, social equity and ; the concept stays elusive. Organizations and governments have taken up sustainable development as a desirable objectif and developed metrics for sustainable development, since the Brundtland report and the Rio Summit but implementation has proven difficult.

Matthews and Hammill (2010) note that principal problem since the Rio Summit has been "in designing the move from theory to practice. Here the tenacious grip of technological, political and other constraints becomes clear."

Uptake of sustainable development has also been impeded by development being outlined primarily as economic growth. The problem related to such an approach is that natural resources are in imminent peril of being spent (whether in terms of supply [e.g., oil reserves] or quality [e.g., air or water pollution]).

Addressing this challenge calls in developing countries profound structural changes are required in the ways that societies operate their social, environmental and economic affairs; and difficult choices are required to move from talk to action.

Currently, the global debate about Financial Development is very much ongoing. It is increasingly obvious that the sustainable development of the economy and society creates a crucial and fast growing demand for adequate financing and functional financial instruments and markets, and is a substantial and crucial area in which to apply sustainable finance and financial market policy. For instance, the challenges and incentives for companies, consumer households, and public authorities to internalize negative externalities have become a central issue when integrating SD considerations into investment and management decisions (UNEP Finance Initiative, 2007).

Past studies have shown that developing countries can approach the MDG target is to accelerate economic growth. The empirical growth literature finds a positive effect of financial depth as measured by, for instance, private domestic credit and liquid liabilities (Norman \& Romain, 2005).

The paper stain to study until what extent the development of the financial sector in developing countries can contribute to the improvement of sustainability development. More specifically, the objectives of this paper are to identify the various channels through which financial development influence the pillars of sustainable development, economic, social and ecological.

The paper utilizes aggregate annual panel data, on a sample composed of 20 developing countries, from 1995-2011 to estimate a model that capture the interrelationship between financial development and ecological sustainability.

The remainder of the paper is organized as follows. In section we start by providing two presents an overview of the literature on the relation connecting on the relationship connecting financial development and environmental sustainability. We explore in the same section the relation between economic growth and ecological dimension.

Section three presents an econometric analysis of financial development an Ecological Sustainability and shows 
empirical model specification and describes data. As well as Section four presents the results and discuss the findings. Section five concludes.

\section{Relationship between Financial Development and Environmental Sustainability}

\subsection{Literature Review}

There are various financial crises, economic, energy, food, climate and ecological which give the opportunity to imagine another world. This is a golden opportunity to restore sensation to development and progress. All we can hope is that basic needs are met one day supply, education, employment, energy, social and health services. We cannot continue with the creation of artificial needs that drain our economies and natural resources of the earth. The priority of the humanist ecology is to conserve, recycle, regulate, reduce, reuse, what the world offers us today and especially tomorrow. But that is not enough, it is imperative that man put his hand to the dough and develops the natural resources of the planet (MÜller, 2001).

The XXI Century has seen a general worldwide crisis; the capitalist mode of production has expanded to the entire world and submits to the reign of the commodity all human activities. However, it produces a major degradation affecting the nature and ecosystems alarmed by depletion of certain non-renewable resources and pollution.

In this context, in 1951, IUCN (International Union for Conservation of Nature) published the first report on the State of the Environment in the World, report precursor in seeking reconciliation between economy and ecology.

The 60s have been marked by the novice fact that economic activities generate harm to the environment (waste, factory fumes, pollution of rivers, etc.), the Club of Rome denounced in 1970 (Limits to Growth) (Donella et al., 1970), the danger of exponential economic and demographic growth in terms of depletion of resources (energy, water, soil), pollution and over-exploitation systems natural.

The United Nations Conference on the Human Environment in Stockholm (1972), the review of the links between environment and development led by Maurice Strong, his organizer, allows introducing a model of economic development compatible with social equity and ecological prudence, which would be based on the satisfaction of needs rather than an uncontrolled increase of the offer. Ecodevelopment concept was born, resumed by the French Ignacy Sachs, which sees the means of reconciling human development and the environment, inseparable from each other, and affirms the necessity of reasons put the north and south development modes, poverty and environmental degradation generators.

This conference it leads to the creation of the United Nations Environment Programme (UNEP), the complement to the United Nations Development Programme (UNDP).

The 80s allow the public to discover the existence of pollution beyond the borders, and global imbalances, such as the "hole" in the ozone layer, acid rain, desertification, global warming, deforestation. In 1987, the report Our Common Future by the World Commission on Environment and Development (Brundtland Commission called the name of Gro Harlem Brundtland who presided) embodies the term "Sustainable Development", proposed by IUCN in 1980 in its report on the World Conservation Strategy. It is defined as "development that meets the needs of the present without compromising the ability of future generations to meet their own needs."

Sustainable development will be devoted by 182 states during the United Nations Conference on Environment and Development (UNCED, or the Earth Summit) in 1992 in Rio de Janeiro. The World Conference on Human Rights to be held in Vienna in 1993, emphasize on the right of people for a healthy environment and the right to development, two requirements controversial and that some Member States had opposed until at the Rio Summit.

The Rio de Janeiro Conference (1992) adopted resolutions to avoid global warming, protect biodiversity and stopping deforestation and pollution. At the moment, the implementation of these resolutions is not very advanced.

While the dynamics of capital accumulation causes more and more non mastered damage to ecosystems, pressure is growing that is entrusted to the care market mechanisms to restore the ecological balance and compromise to protect future. We talk to that level of environmental concept of sustainable development based on the need to preserve the integrity and productivity of environmental systems in the world that help perpetuate the life cycle.

UNCTAD established a decisive stage in the commitment of countries in favor of sustainable development: There will be formulated its aims, principles ... there will be consolidated the emergence of new types of multilateral environmental agreements:

\section{- Multilateral Environmental Agreements (MEA) and binding conventions:}

Concern over the environmental pollution and depletion of natural resources has led, dice the $60 \mathrm{~s}$, to the emergence of binding instruments, such as Multilateral Environmental Agreements (MEA). The first generation of 
MEA is essentially "sectoral": it concerns agreements on a single issue on the preservation of a particular resource (fauna, flora, birds, marine environment, air). Basel Convention on the Control of Transboundary Movements of Hazardous Wastes and their Disposal, Basel, 1989. Vienna Convention for the Protection of the Ozone Layer and the Montreal Protocol on Substances that Deplete the Ades Ozone Layer, 1987. United Nations Convention on the Law of the Sea, Montego Bay, 1982. Convention on the Conservation of Migratory Species of Wild Animals, Bonn, 1979. Convention on International Trade in Endangered Species of wild fauna and flora threatened with extinction,Washington, 1973. Convention relative to the wet zones of internationalimportance, Ramsar, on 1971. Convention concerning, the Protection of World Cultural and Natural Heritage, 1972.

The second generation of AME comes from Stockholm in 1972. UNCED marked a real consolidation of AME second generation, through the adoption of two conventions which confirm the commitment "common but differentiated" of states to confront global environmental issues (Dale et al., 2010; Chasek, 2005).

The framework convention on climate change is aimed at the 'stabilization of concentrations of greenhouse gases in the atmosphere at a level that would prevent dangerous anthropogenic interference with the climate system'.

The OECD countries committed to stabilize in 2000 emissions of greenhouse gases at the same level as in 1990. In 1997, the Kyoto protocol sets goals of reduction for industrialized countries beyond the year 2000: $5.2 \%$ over the period 2008-2012 compared to 1990 for developed countries, $8 \%$ for the European Union, 0\% for France. In the course of the conferences of the parts: Buenos Aires (1998), Bonn (1999), The Hague (2000), the application of the Kyoto Protocol (Carr \& William, 1998; Dawson, 1999) is facing increasing challenges, especially on the practical implementation of flexibility mechanisms ("pollution permits, clean development").

The Convention on Biological Diversity recognizes for the first time that the conservation of biological diversity is "a common concern of humankind" and an integral part of the development process. It sets three objectives: the conservation of biological diversity, the sustainable use of its components and equitable sharing of benefits arising from the utilization of genetic resources. It extends to the field of biotechnology.

\section{- New action principles of the Rio Declaration:}

Rio allowed the adoption of the Statement of principles relative to forests and the Declaration of Rio on the Environment and the Development: these texts legally non-binding affirm the purposes of actions and principles that refer to other international commitments and many national policies. It's about to place human beings at the center of concerns for sustainable development, as they are entitled to a healthy and productive life in harmony with nature, including the fight against poverty in compliance with present and future generations. Also it's about to preserve the global balances and environmental resources for long-term development, deflecting modes of development and eliminating patterns of production and non-durable consumer the benefit of those whose distribution would be sustainable must be promoted (United Nations, 1992).

\section{An action program for the XXI Century The States present at Rio also adopted Agenda 21 (commonly known as the Rio Agenda21):}

It is a comprehensive program of action to be implemented by governments, development agencies, UN organizations and independent sectors groups in every area in which human activity affects the environment.

\subsubsection{The Relationship between Economic Growth and Environment}

Environmental pollution is presented both as a product and as a common source of disutility in growth patterns. The aim is to explore the key issues such as: environmental protection is compatible with economic growth? Is it possible to have a sustained growth without long-term accumulation of pollution? What is the impact of environmental issues on growth, and in particular, how the growth rates they affect variables such as capital, income, consumption or pollution of the environment? What are the stylized facts about the quality of the environment and economic development? (Environmental Kuznets curve). 


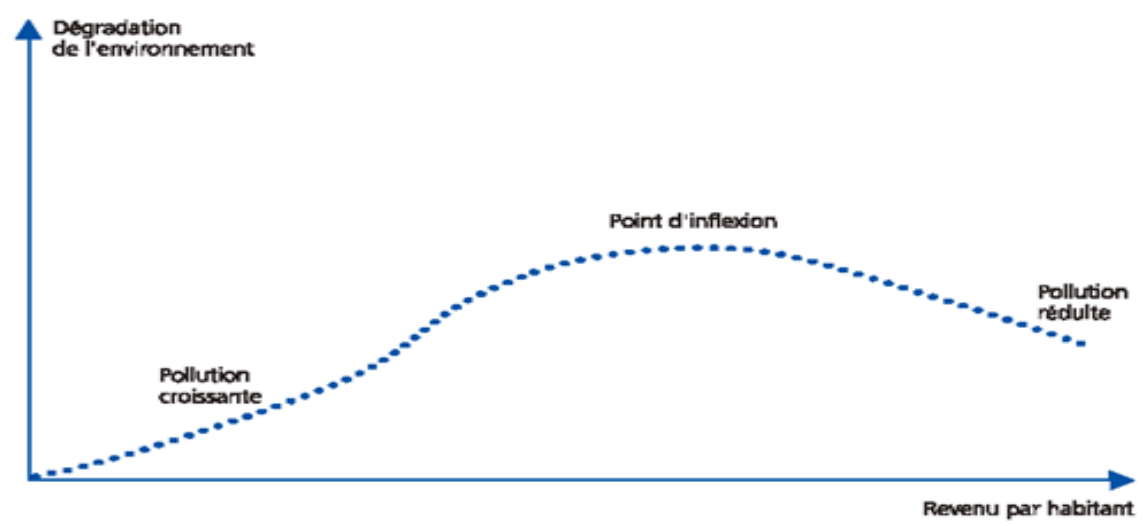

Figure 2. La courbe environnementale de Kuznets Source: OMC (1999)

In developed countries, the enrichment of the population is accompanied by the application of a cleaner environment, which causes an improvement in the quality of the environment. For example the case of air pollution in cities. This approach leads to the assumption that growth is bad for the environment in the early stages of development and, beyond a certain threshold of per capita income. Growth would become a source of improvement of the environment of the individual.

Simon Kuznets (1955) is based on the idea that the environment would be "well above", that is to say, a much needed such as health and recreation, and increases with the increase of income. However, for the poor, basic needs such as food, housing, clothing does not leave room for other occupations. Moreover, GDP growth can devote part of environmental funding (Anastasios, 2003).

\subsubsection{Financial Development and Ecological Dimension}

\section{A. Renewable Energy Technology}

Finance ecological dimension is a sectoral concept based on the role of the financial services and Financial intermediation, particularly commercial banking for the production of renewable energy. This role is very important when considering non-hydro renewable energy as, wind energy, solar, geothermal and biomass.

Today, the realization of a diversified and sustainable energy supply for future generations is one of the major challenges for researchers; since global energy demand will grow by nearly 45 percent in 2030. Energy demand will continue to be covered primarily by conventional fossil fuels like coal, oil and natural gas which are therefore related to pollution resulting from energy. In addition to many estimates predict that oil production and natural gas may be a risk to future energy security. Therefore, the realization of a sustainable energy supply requires diversification of energy sources and a change in the current dependence on non-renewable hydrocarbons and polluting fuels (Christa, 2009).

Recently, the renewable energy technology (TER) (include hydroelectric technologies, new technologies that harness wind, solar, biomass and geothermal energy) can be beneficial to the environment and advantageous to the economy social. Generally, it incites to rationalize local resource use, to promote the basic electrification in developing countries, and to increase energy security.

However, although there TER commercially available and economically attractive, they still represent only a small proportion of global energy production. This fact suggests that there are channels missing from the potential of renewable energy technologies and their implementation, that is to say a problem that concerns the institutional framework and the lack of a policy to effectively promote TER (Sonntag-O'Brien \& Eric, 2004).

At this level we focus on the financing of renewable energy projects, in particular, the relationship between the financial sector and the TER development (Brunnschweiler, 2010; Christa, 2009).

Generally, energy projects require high levels of funding. In his turn, funding for TER is closely linked to the development of the financial sector. The privatization of the energy sector and the liberalization over the years (1990) increased the contribution of small private projects to electrics, and at the same time they led a change in the external financing of the government (Babbar \& Schuster, 1998; Tharakan et al., 2007; Tirpak \& Adams, 2008 ). On the other hand, the projects of the renewable energies have very big start-up costs compared the expected 
monetary returns and recovery. They need a long-term maturity loans.

The problem of financing renewable energy projects is twofold: first, RET businesses have a need for long-term loans, the availability of which in turn is positively related to the development of the banking system (Demirguc-Kunt \& Maksimovic, 1999). Second, access to finance technology companies in the renewable energy is limited because of competition from fossil fuel projects that have relatively lower initial costs and favorable policy treatment (Churchill \& Saunders, 1989; Head, 2000).

Over the past two decades, analyzing the role of the financial sector, such as commercial banking, financial markets and insurance, has generated a vast literature (Demirguc-Kunt \& Levine, 2001). The importance of the private financial sector in particular for the development of the energy sector has also been highlighted in several studies.In one of the first analyzes of the financing of the energy sector in developing countries, Churchill and Saunders (1989) present a real political framework to encourage private financial sector.

Later, Babar, Schuster (1998), Head (2000) and Painuly Wohlgemuth (1999) also found significant gaps in financing renewable energy projects.

More recently, Sonntag-O'Brien,Usher (2004) and Painuly, Wohlgemuth (2006) have implemented the technology of renewable energy RET in developing and transition countries.

MacLean and Siegel (2007) focused their work on the financing of renewable energy projects on a small scale and have identified three areas of funding: "End-User Finance", "Finance Business" and "Small-Scala Project Finance".

\section{B. The Visions of the Environmental Management}

Economic interpretations that follow "The Brundtland Report" gives rise to two concepts: low Sustainability and Strong sustainability.

\section{1) The low Sustainability: A neoclassical vision}

The weak sustainability is based on the Hotteling theory (1931) which the price of a resource changes according to its rarity and finds its exit in the rule of compensation of Hartwich (1997). He showed that the rents equal to the difference between price and marginal cost of funds, they must be reinvested to produce substitute capital for depleted resources. Finally grow from period to period; then the intergenerational equity is guaranteed.

Both approaches aim to integrate the environment into economic calculation via the externality, which can analyze the economic costs of environmental degradation on other agents. It includes the positive impact of economic activities and an external effect can be negative on the environment and eventually to all communities of the world. This is the case of public transport of goods responsible for $\mathrm{CO} 2$ emissions. At this level, public transport of goods although they facilitate the economic process, they have a negative impact through $\mathrm{CO} 2$ emissions they generate. How economists do they intend applying these principles? It is through internalization of externalities that can be made according to two modalities:

\section{1st instrument: pricing}

There is talk of a "Pigovian tax", which covers the concept of tax to internalize the marginal social cost of economic activities in the market; especially as regards pollution (Arthur Pigou, 1920). In this context the principle of "polluter pays" ensues. The analysis of Pigou is to say that if a company creates negative externalities, so pollutes, then the social marginal cost of production is higher than the private marginal production cost.

The only way to return to a Pareto optimum position is to bridge the gap between social and private cost. This is called internalizing the externality.

The tax of "Optimal Pigou" is strongly conditioned by the economic evaluation of externalities which is difficult because it is very subjective and arouses passions. In addition, we do not know the shape of the function of an external cost.

The economic optimum can be achieved for the company to the point where the marginal cost of treatment equalizes the marginal social cost of damages that are an increasing function of the damage. There is still a certain level of pollution, but it requires a higher cost than the damage. Taxation correct resource allocation modifying the relative prices of products, so as to recover an optimal situation.

Indeed as the marginal cost of conservation measures is less than the amount of tax, each agent has an incentive to reduce environmental accomplished. While taxation allows the equalization of marginal costs of protection for all agents. Taxes being returned on the price of the final product sold to the consumer, it is also invited to reorient its choice. In this context, taxation should seek to reduce clean-up costs since pollution will be less. Vice versa, if an 
agent is at the origin of favorable external effects for the natural or social environment, a system of subsidies allows to pay the services which it returns to the community.

So, the principle "polluter pays" can be put into realization provided that stringent assumptions are met. Thus, we need to determine the amount of tax and the optimal pollution level. Thus, he assumes to know the functions of the cost of polluting enterprises and marginal disposal to pay of the economic agents.

The optimal rate of taxation helps to know at what level fixed uniformity between the marginal social cost of pollution reduction and value of the marginal social damage (Godard, Henr, 1998). Other forms of taxes on tobacco or alcohol, the Carbon tax are an example of "Pigovian tax".

\section{Second instrument: the right to pollute emission}

By opposition to Pigou, Coase (1960) suggested the tax payment distribution of damages between polluter and polluted because the tax would have the perverse effect of reducing the production realized by the polluter. $\mathrm{He}$ proposed to remedy the market failure and restore a Pareto optimum in establishing transferable property rights to environmental resources.

Coase's proposal reflects that technical progress is likely to provide solutions against the negative externality. Indeed, placing on the market of the authorities to pollute; i.e environmental portions to a non-zero price, suppose the output being obtained from factors substitutable continuously: 1- Just over environment that release a little more polluted for those who will buy the licenses and a little less investment in clean technology. 2- A little investment in clean technologies and a little less of access to the environment for those who sell their licenses.

\section{2) Strong sustainability: Ecological Vision}

The approach of the strong sustainability is based on the following constraints:

1- The renewable natural resources utilization should not exceed their regeneration rate. 2- Exhaustible resources should be extracted at a rate to their replacement by renewable resources. 3- Unlike the neoclassical strong sustainability assumes that natural capital and the artificial capital are complementary and not substitutable (Daly 1990). 4- Prevention principle: prevent pollution rather than compensate monetarily. 5- Insertion of the economy in the biosphere.

\section{An Econometric Analysis of Financial Development an Ecological Sustainability}

\subsection{Model Specification}

Based on theoretical analysis on ecological sustainability and to assess the impact of the financial development, we adopted a standard model building on previous studies. The model explains ecological sustainability by a core set of control variables, Investment in the industrial sector, Life expectancy at birth, total (years). These variables are expected to influence positively the ecological sustainability.

We add growth of GDP per capita, to capture the contribution of economic development. It is incorporated in the model to reflect the level of development of the economic system. We therefore expect a positive coefficient of this variable.

The baseline model is then augmented with the financial development measured by domestic credit to private sector to GDP (DCPS) and Money and quasi money M2 as \% of GDP(LIQI). The following presentation of the structure of the model of regression is based on a static specification.

To test the importance of financial development in determining the ecological sustainability, we adopted the following model:

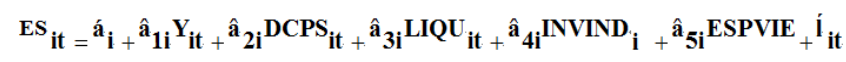

Where it $E S_{i t}$ is the indicator of Ecological Sustainability for a country $\mathbf{i}$ at a period t. $Y_{i t}, I N V I N D_{i t}$ and $E S P V I E_{i t}$ are a set of potential ecological sustainability determinants(cited above). DCPS $S_{i t}$ and $L I Q U_{i t}$ are indicators of financial development and $\xi$ it is the error term.

\subsection{Definitions of Variables}

We compiled data for a sample of 20 developing countries over the period 1995-2011. The sample sizes and the period of study are limited by the availability of data on control variables.

Ecological sustainability $\left(\mathbf{E S}_{\mathrm{it}}\right.$ ): it is measured by the pollution rate: $\mathrm{CO} 2$ emissions ( $\mathrm{kg}$ per PPP \$ of GDP) "Carbon dioxide emissions are those stemming from the burning of fossil fuels and the manufacture of cement. They include carbon dioxide produced during consumption of solid, liquid, and gas fuels and gas flaring" 
(http://data.worldbank.org/indicator/EN.ATM.CO2E.PP.GD).

Ecological Sustainability is the capacity of ecosystems to maintain their essential functions and processes, and retain their biodiversity in full measure over the long-term (Morelli, 2011).

Also Ecological sustainability refers to the capacity of the biosphere to meet the needs of the present generation, without hindering future generations from being able to meet their needs. This means using our natural resources wisely in the short-term so that these resources are available in the long-term. Ecological sustainability relies on the fact that humans have the ability to exhaust (overuse) our natural resources, leaving nothing but polluted water and infertile soil for future generations. Ecological sustainability is the belief that all humans must use resources wisely and efficiently so that these resources never become exhausted or over-polluted (John \& Deborah, 2010; Callicott \& Karen, 1997).

Understanding and use of the word "environmental" quite often tends to be associated with some kind of human impact on natural systems. This context distinguishes it from the word "ecological," which can be characterized as a concept of interdependence of elements within a system. As discussed above in the essay, "Ecological Sustainability as a Conservation Concept," the authors suggest that an ecological definition of sustainability be advanced that is in better accord with biological conservation. Their suggestion was that ecological sustainability is "meeting human needs without compromising the health of ecosystems." (Adams, 2008).

This seems inappropriate in that the general perception of the word "ecological" is that it implies a broader context than just the human experience. The word "environmental," however, is almost always used in reference to human interaction with the ecosystem. To increase precision, it thus seems reasonable to view "environmental" as a subset of the broader concept of "ecological," i.e., the intersection of human activities and ecological systems (Butle, 2009; )

Herman Daly (1990), one of the early pioneers of ecological sustainability, looked at the problem from maintenance of natural capital viewpoint. In 1990 he proposed that: 1- For renewable resources, the rate of harvest should not exceed the rate of regeneration (sustainable yield); 2- For pollution The rates of waste generation from projects should not exceed the assimilative capacity of the environment (sustainable waste disposal); and 3- For nonrenewable resources the depletion of the nonrenewable resources should require comparable development of renewable substitutes for that resource.

Basically the world's standard definition of environmental sustainability is sustainable development, which means sustainable economic growth, which is an oxymoron. No form of economic growth can be continued indefinitely. Furthermore, all economic growth today is terribly environmentally degrading. Thus it's impossible to be sustainable and achieve economic growth at the same time, now and for at least the next 50 years or so.

Financial Development: it is measured by the ratio of domestic credit provided by banking sector relative to GDP and Money and quasi money (M2) as \% of GDP. These indicators are generally used in empirical studies.

\subsection{Descriptive Analysis}

Table 1. Descriptive statistics of the explanatory variables and the dependent variable

\begin{tabular}{lccccc}
\hline Explanatory variables & Observations & Standard deviation & Average & Minimum & Maximum \\
\hline Co2 & 340 & 429165,1 & 306657,5 & 385,035 & 19799425 \\
GDP & 340 & 1992,382 & 2491,841 & 367,277 & 11601,063 \\
DCPS & 340 & 32,28774 & 47,93184 & 1,38 & 208,184 \\
LIQU & 340 & 41,56001 & 64,14809 & 10,36 & 247,824 \\
INVIND & 340 & 7,8147 & 32,15587 & 14,69 & 48,53 \\
ESPVIE & 340 & 5,81875 & 68,34658 & 50,92 & 75,79 \\
\hline
\end{tabular}

- The CO2: has a standard deviation equal to $(429165,1)$ and an average of $(306657,5)$. Regarding the minimum value has a value (385.035) and a maximum value to $(19,799,425)$.

- $\quad$ The Growth of GDP per capital: has a standard deviation equal to $(1992,382)$ and an average of $(2491,841)$. A minimum of (367.277) and a maximum of $(11,601.06)$.

- Domestic Credit to private sector to GDP (DCPS): has a standard deviation equal to (32.28774) and an average of (47.93184). Maximum to (208.184) and minimal equal to (1.38). 
- $\quad$ Investment in the industrial sector: has a standard deviation equal to $(7,8147)$ and an average of $(32.15587)$. Thus for a minimum value $(14,69)$ and a maximum value $(48.53)$.

- Life expectancy at birth, total (years): has a standard deviation equal to (5.818) and an average of (68.64). Thus, a minimum and a maximum value are respectively equal to $(50,92)$ and $(75,79)$.

\section{Dependence between variables in our database}

To award the existence of dependency relationships between different variables in our database, we refer to the functions of correlations and covariance matrices. From these dependency functions we identify the presence or absence of relations between the endogenous variable and the explanatory variables.

Table 2. Correlation matrix of variables of interest

\begin{tabular}{cllllll}
\hline variables & Co2 & GDP & DCPS & LIQU & INDS & ESPVIE \\
\hline Co2 & $\mathbf{1 . 0 0 0}$ & & & & & \\
GDP & -0.1415 & $\mathbf{1 . 0 0 0 0}$ & & & & \\
DCPS & -0.2141 & 0.0400 & $\mathbf{1 . 0 0 0}$ & & & \\
LIQU & -0.2672 & 0.2128 & 0.5660 & $\mathbf{1 . 0 0 0}$ & $\mathbf{1 . 0 0 0}$ & $\mathbf{1 . 0 0 0}$ \\
INVIND & 0.1588 & -0.0034 & -0.0350 & $\mathbf{- 0 . 0 9 0 7}$ & $\mathbf{0 . 3 5 3 0}$ & $\mathbf{0 . 1 8 3 9}$ \\
ESPVIE & -0.2185 & 0.3778 & -0.1694 & $\mathbf{0 . 3 5 0}$
\end{tabular}

From this matrix we can notice that there is not a Multi-collinearity problem between the explanatory variables because the correlation coefficients between these variables are very low.

\subsection{Estimation Techniques}

\subsubsection{Static Estimate}

The test specifications show that our theoretical model can be formalized as a panel with individual effects. The table below summarizes the two procedures of estimates in the observation of static relationships that describe the linear equation that relates ES according to the explanatory variables.

Table 3. Estimated of ES

\begin{tabular}{lcccc}
\hline & \multicolumn{2}{c}{ Fixed effect estimation } & \multicolumn{2}{c}{ Random Effects Estimate } \\
\cline { 2 - 5 } Explanatory variables & Coefficients & Significance & Coefficients & Significance \\
\hline GDP & 17.73234 & 0.116 & 16.89309 & 0.127 \\
DCPS & -216.6533 & 0.393 & -202.7603 & 0.424 \\
LIQU & 412.1309 & 0.347 & 391.8108 & 0.367 \\
INVIND & 6462.758 & 0.001 & 6575.544 & 0.001 \\
ESPVIE & 15678.65 & 0.000 & 14666.07 & 0.000 \\
\hline
\end{tabular}

\subsubsection{Hausman Test (1979)}

The specification of Hausman Test is a general test which can be applied to many problems econometric specification. But its most common application is that of specification tests of the individual effects panel data. It thus serves to discriminate the fixed and random effects.

The general idea of this test is both simple and ingenious. This test seeks to study the possibility of a correlation or default specification, assuming that we have two types of estimators for the parameters of our basic model. The first estimator is supposed to be unbiased estimator with minimum variance under the null hypothesis of correct specification of the model (no correlation).

However, under the alternative hypothesis of poor specification, this estimator is supposed to be biased. Both hypotheses Hausman can be specified as follows:

$$
\left\{\begin{array}{l}
H_{0}: \mathrm{E}\left(\alpha_{\mathrm{i}} / X_{i}\right)=0 \\
H_{a}^{3}: \mathrm{E}\left(\alpha_{\mathrm{i}} / X_{i}\right) \neq 0
\end{array} \quad \forall \mathrm{X}_{\mathrm{i}}\right.
$$

: The matrix of explanatory variables. 


$$
H=\left(\beta_{k}^{F}-\beta_{k}^{A}\right)^{\prime}\left(\operatorname{Var}\left(\beta_{k}^{F}-\beta_{k}^{A}\right)\right)^{-1}\left(\beta_{k}^{F}-\beta_{k}^{A}\right) \quad \forall \mathrm{k}=1,2,3,4,6, \ldots 20
$$

$\beta_{k}^{F}$ : is the vector of estimators within. $\beta_{k}^{A}$ : is the vector of estimators between.

Under the null hypothesis of correct specification, this statistic is asymptotically distributed as a chi-square with $\mathrm{k}$ degrees of freedom. Thus, under the null hypothesis that the theoretical model can be specified with random individual effects. By against, under the alternative hypothesis, the model must be specified with fixed individual effects and must retain the within or LSDV estimator (the unbiased estimator).

The table below summarizes the Hausman test (1978) for the development of financial contribution in the environmental field for 20 countries during a study period from 1995 to 2011.

Prob $>$ Chi2 $=0.0216<0.05 \square$ So we must choose the fixed effect.

Table 4. Fixed effect estimation

\begin{tabular}{lcc}
\hline Variables explicatives & Coefficients & Significativité \\
\hline Y & 17,73234 & 0,116 \\
DCPS & $-216,6533$ & 0,393 \\
LIQU & 412,1309 & 0,347 \\
INVIND & 6462,758 & 0,001 \\
ESPVIE & 15678,65 & 0 \\
\hline
\end{tabular}

\subsubsection{Test Residue}

The problem autocorrelation: In estimation we note that there is a problem since autocorrelation gets that (Prob $>\mathrm{F}$ $=0.000)<0.05$. The problem of Heteroscedasticity (see Annex 1): According to our estimates, we find that there is a problem since we hetero-scedasticity $($ Prob $>F=0.3385)>0.05$.

\section{Main Results and Discussion}

\subsection{Correction Autocorrelation and Hetero-scedasticity Result}

The regression results that we have made over the period 1995-2011 are presented in the table presented below.

Table 5. Error correction

\begin{tabular}{llll}
\hline Explicatif variables & coefficients & Standard deviation & $\mathrm{P}>|\mathrm{z}|$ \\
\hline GDP & 10,96406 & 4,385095 & $0,012^{* *}$ \\
DCPS & 10,63742 & 174,3521 & 0,951 \\
LIQU & $-397,3298$ & 208,1857 & $0,056^{* * *}$ \\
INVIND & 2085,741 & 730,6688 & $0,004^{* *}$ \\
ESPVIE & $-1535,766$ & 1624,169 & 0,344 \\
Notes. * significant at 10\%, ** Significant at 5\%; *** Significant at 1\%.
\end{tabular}

\subsection{Discussion}

$>$ We note that, the coefficient of Financial Development measured by domestic Credit to Private Sector to $G D P$ is not significant proving that financial system cannot contribute to the improvement of pollution rate in developing countries.

$>$ An inverse relationship between the Money supply M2 in percentage of GDP that defines financial development) and Environmental Sustainability. This means that financial development leads to a reduction in pollution.

This due to the different instruments of the fight against pollution and performance analysis. The instruments considered are: moral persuasion, establishing standards; economic instruments, which find their origin in the theory of externalities.

In fact Pollution in this context is considered a "bad" public or social costs resulting from the production of goods. Being a nuisance or externality, we must associate a cost purpose goods producers consider this public 
evil in their decisions about products, processes and production technologies. There are several categories of economic instruments such as taxes, subsidies, deposit system -Refund and creating the market.

A positive relationship between the rate of pollution and Industrial Investment( INVIND). The increase in industrial investment entails an increase in pollution. This is explained in simple terms, that pollution is contamination by a chemical substance or other pollutants that make part of the unsuitable environment. It is triggered by industrial waste, agricultural practices, human activities and in particular, modes of transport and many other sources. Pollution has many forms: it can be chemical substances or energy, such as sound, heat or light. The Air Pollution, the Water Pollution, Noise pollution.

$>$ A positive relationship between the pollution levels represented by the $\mathrm{CO} 2$ indicator and Economic Growth, in the sense that high growth can lead various pollutants (asbestos, oil spills ...). In addition to high growth can negatively affect biodiversity, it generates a climate change (rising temperatures, changing rainfall patterns ...) that will have many negative consequences such as, natural disasters, draining ... etc.

\section{Conclusion}

Sustainable development is a complex concept of the world's and is an major challenge for all countries. For that reason, some authors have argued the essential role of financial development to stimulate the various pillars of this concept, respectively, the economic pillar, ecological and social.

The objective of this paper is to study how the financial system in developing countries contributes to the improvement of sustainable development focusing particularly on the environmental pillar.

Estimations are conducted with a panel data of 20 development countries over the period of 1995-2011 using Econometrics static panel. Our findings show that financial system in developing countries generally has a favorable impression on Environmental Sustainability. Unfavorable effect for industrial investment and economic growth, but in contrast, in insignificant effect for domestic credit provided by banking sector relative to GDP and Life expectancy at birth, total (years).

When the first part the theoretical study, she identified the harmful implications of the mode of production such as industry on natural resources, depletion of non-renewable natural resources, pollution of air and water . In this context, the empirical study identified that in the case of developing countries, industries emit the expected pollution levels.

\section{References}

Adams, W. M. (2008). Green Development: Environment and Sustainability in a Developing World (3rd ed.). Routledge, London. First Published in 1991 as Green Development: Environment and Sustainability in the Third World.

Anastasios, X. (2003). Economic Growth and the Environment (pp. 74-100). University of Crete, Department of Economics University Campus.

Arthur, C. P. (1920). The Economics of Welfare. Retrieved fropm http://oll.libertyfund.org/EBooks/Pigou_0316.pdf

Brunnschweiler, C. N. (2010). Finance for Renewable Energy: An Empirical Analysis of Developing and Transition Economies. Environment and Development Economics, 15(3), 241-274. http://dx.doi.org/10.1017/S1355770X1000001X

Butle, B. P. (2009). Ecological Balance: The Greater Goal of the Environmental Manager (Graduate Thesis). Rochester Institute of Technology, Rochester, NY, USA.

Callicott, J. B., \& Karen, M. (1997). Ecological Sustainability as a Conservation Concept. Conservation Biology, 11(1), 32-40. http://dx.doi.org/10.1046/j.1523-1739.1997.95468.x

Carr, D. A., \& William, L. T. (1998). The Kyoto Protocol and US Climate Change Policy: Implications for American Industry. RECIEL, 7(2), 191-201. http://dx.doi.org/10.1111/1467-9388.00146

Chasek, P. (2005). The Negotiating System of Environment and Development: A ten-year review. Global Challenges: Furthering the multilateral policy process. Sheffield, UK: Greenleaf Publishing.

Christa, N. B. (2009). Finance for Renewable Energy: An Empirical Analysis of Developing and Transition Economies. CER-ETH - Center of Economic Research at ETH Zurich.

Churie, A., Sjöstedt, G., \& Corell, E. (Eds.). (2005). Global Challenges: Furthering the Multilateral Process for 
Sustainable Development. Greenleaf Publications.

Dale, A., \& Newman, L. (2010) Social capital: A necessary and sufficient condition for sustainable community development? Community Development Journal, 45(1), 5-21. http://dx.doi.org/10.1093/cdj/bsn028

Daly, H. E. (1990a). Boundless bull. Gannett Center Journal, 4(3), 113-118.

Daly, H. E. (1990b). Toward Some Operational Principles of Sustainable Development. Ecological Economics, 2, 1-6. http://dx.doi.org/10.1016/0921-8009(90)90010-R

Dawson, G. (1999). Market Exchange, Social Contract and the Kyoto Protocol. Risk Decision and Policy, 4(3), 163-177. http://dx.doi.org/10.1080/135753099347932

Donella, H. M., Dennis, L. M., Jtsrgen, R., \& William, W. B. III. (1970). A Report for THE CLUB OF ROME'S Project on the Predicament of Mankind. The limits to growth. Library of Congress Catalog Card Number: 73-187907. $\quad$ Retrieved

from http://collections.dartmouth.edu/published-derivatives/meadows/pdf/meadows_ltg-001.pdf

Harold, H. (1931). The Economics of Exhaustible Ressources. The Journal of Politicla Economy, 39(2), Retrieved from http://msl1.mit.edu/classes/esd123/2003/bottles/Hotelling.pdf

http://data.worldbank.org/indicator/EN.ATM.CO2E.PP.GD

International Training Centre of the International Labour Organization. (2014) Campinas 2014 Social and Solidarity Economy: Towards Inclusive and Sustainable Development: 28th July-1st August 2014, Campinas, Brazil.

John, D., \& Deborah, M. (2010). Sustainable Development: From Brundtland to Rio 2012. International Institute for Sustainable Development (IISD), United Nations Headquarters, New York.

Leuphana University. (2010). Sixth International Environmental Management Leadership Symposium. 22-23 Mar., 2010. Leuphana University, Lüneburg, Germany.

Matthews, R. A., \& Anne, H. (2010). Sustainable Development and Climate Change. International Affairs, 85(6), 1117-1128. http://dx.doi.org/10.1111/j.1468-2346.2009.00852.x

Morelli., J. (2011). Environmental Sustainability: A Definition for Environmental Professionals. Journal of Environmental Sustainability, 1(1). http://dx.doi.org/10.14448/jes.01.0002

Muller, F. (2001). Environmental Economics and Ecological Economics: Antagonistic Approaches. International Journal of Environmental Studies, 58, 415-443. http://dx.doi.org/10.1080/00207230108711342

Najam, A. (1999). World Business Council for Sustainable Development: The Greening of Business or a Greenwash? Yearbook of International Cooperation on Environment and Development, 2000, pp. 65-75.

Norman, L., \& Romain, R. (2005). Financial Development, Financial Fragility and Growth. Retrieved from https://www.imf.org/external/pubs/ft/wp/2005/wp05170.pdf

Rio Declaration on Environment and Development. (1992). Retrieved from http://www.unep.org/Documents.Multilingual/Default.asp?documentid=78\&articleid=1163

Sonntag-O'Brien, V., \& Eric, U. U (2004). Mobilising Finance for Renewable Energies. Retrieved from http://siteresources.worldbank.org/EXTRENENERGYTK/Resources/51382461237906527727/5950705-12 39134575003/mobfin0mfretb003.pdf

Steven, G. M., Richard, O., \& Zerbe, Jr. (1999). The Coase Theorem. University of Colorado at Denver. University of Washington, Graduate School of Public Affairs.

Thorsten, B., \& Demirgüç-Kunt, A. (2009). Financial Institutions and Markets across Countries and over Time. Development Research Group Finance and Private Sector Team.

Thorsten, B., Demirgüç-Kunt, A., \& Vojislav, M. (2004). Financing Patterns Around the World: Are Small Firms Different? http://siteresources.worldbank.org/DEC/Resources/847971114437274304/FinancingPatterns_Aug2004-revi sions.pdf

UNDP. (2011). Sustainability and equity: A better future for all. United Nations Development Programme (UNDP): Human Development Report.

United Nations (UN). (1992). Rio Declaration on Environment and Development. Retrieved from http://www.jus.uio.no/lm/environmental.development.rio.declaration.1992/portrait.a4.pdf 
United Nations Headquarters. (2010). Sustainable Development: From Brundtland-to-Rio2012. United Nations Headquarters, New York.

United Nations. (1972). Report of the United Nations Conferences of the Human Environment. Stockholm. Retrieved from http://www.un-documents.net/aconf48-14r1.pdf

\section{Copyrights}

Copyright for this article is retained by the author(s), with first publication rights granted to the journal.

This is an open-access article distributed under the terms and conditions of the Creative Commons Attribution license (http://creativecommons.org/licenses/by/3.0/). 